\title{
Conservation of the Name Micropolyspora Lechevalier, Solotorovsky, and McDurmont and Designation of Micropolyspora faeni Cross, Maciver, and Lacey as the Type Species of the Genus
}

Request for an Opinion

\author{
A. J. MCCARTHY, ${ }^{1}$ T. CROSS, ${ }^{1 *}$ J. LACEY, ${ }^{2}$ AND M. GOODFELLOW ${ }^{3}$ \\ School of Biological Sciences, University of Bradford, Bradford BD7 IDP, ${ }^{1}$ Rothamsted Experimental \\ Station, Harpenden ALS $2 \mathrm{JQ}^{2}$ and Department of Microbiology, The University, Newcastle upon Tyne NEI \\ $7 R U,{ }^{3}$ United Kingdom
}

\begin{abstract}
We propose that the Judicial Commission of the International Committee on Systematic Bacteriology conserve the genus name Micropolyspora with Micropolyspora faeni Cross, Maciver, and Lace 1968 (Approved Lists of Bacterial Names, 1980) as the type species. This proposal is made in the interest of nomenclatural stability and in order to avoid confusion in the literature after the reclassification of the original type species, Micropolyspora brevicatena Lechevalier, Solotorovsky, and McDurmont 1969 (Approved Lists, 1980), as Nocardia brevicatena (Lechevalier, Solotorovosky, and McDurmont) Goodfellow and Pirouz 1982 and demonstration of the synonymy of $M$. faeni with Micropolyspora rectivirgula Krassilnikov and Agre 1964 (Approved Lists, 1980). M. faeni is the main causative agent of farmer's lung disease and other forms of hypersensitivity pneumonitis. Consequently, the binomial $M$. faeni has been used in numerous scientific and medical publications, whereas $M$. rectivirgula appears in few. The genus Micropolyspora so conserved would also include Micropolyspora angiospora Zhukova, Tsyganov, and Morozov 1968 (Approved Lists, 1980) and Micropolyspora internatus Agre, Guzeva, and Dorkhova 1974 (Approved Lists, 1980).
\end{abstract}

This request for an opinion concerns two closely related problems arising from recent taxonomic decisions regarding species of the genus Micropolyspora Lechevalier, Solotorovsky, and McDurmont 1961 (Approved Lists of Bacterial Names, 1980). The genus Micropolyspora was erected to accommodate actinomycetes which form chains of spores on both the aerial and substrate mycelia. The type species Micropolyspora brevicatena Lechevalier, Solotorovsky, and McDurmont 1961 (Approved Lists, 1980), was based on two strains isolated from the sputa of patients who had undergone treatment for tuberculosis (28). Other actinomycetes with similar morphology were described by a number of workers, and by 1974 a total of eight species were listed in Bergey's Manual of Determinative Bacteriology (7). Subsequently, three additional species were proposed, and other specific names also appeared in the literature without formal descriptions. When the Ad Hoc Committee of the Judicial Commission of the International Committee on Systematic Bacteriology reviewed bacterial taxa in preparation for the Approved Lists of Bacterial Names (33), taxa were retained only if they were considered to be adequately described and if a type, neotype, or reference strain was available. Only the following five Micropolyspora species filled these criteria: Micropolyspora angiospora, Micropolyspora brevicatena, Micropolyspora faeni, Micropolyspora internatus, and Micropolyspora rectivirgula.

Although the genus Micropolyspora has remained essentially morphological in concept, the possession of wall chemotype IV, as defined by Lechevalier and Lechevalier (30), has become incorporated in the genus definition $(8$, 26). This improved circumscription of the genus resulted in the transfer of "Micropolyspora rubrobrunea" and "Micropolyspora viridinigra" (19) to the genus Excellospora Agre and Guzeva 1975 (Approved Lists, 1980) (1), strains of which have wall chemotype III. However, Micropolyspora remained heterogeneous (12). Mycolic acids similar in chain length to those found in Nocardia sensu stricto were found in the type species, M. brevicatena (5), whereas other species, including $M$. faeni, Cross, Maciver, and Lacey 1968 (Approved Lists, 1980), M. rectivir- 
gula (Krassilnikov and Agre 1964) Prauser and Momirova 1970 (Approved Lists, 1980) $(18,32)$, and "Micropolyspora caesia" did not contain mycolic acids $(5,20,31)$. Data on menaquinones (5), phospholipids (29), and fatty acids (20) also suggested that $\boldsymbol{M}$. brevicatena is more closely related to Nocardia spp. than to members of the genus Micropolyspora. Finally, based on these chemotaxonomic findings and on the results of an extensive numerical phenetic study, Goodfellow and Pirouz (12) proposed that $M$. brevicatena be transferred to the genus Nocardia as Nocardia brevicatena comb. nov. A similar recommendation has been made by Kurup (21).

The reclassification of $M$. brevicatena as $N$. brevicatena $(12,21)$ leaves Micropolyspora without a type species and nomenclaturally invalid (25). The other Micropolyspora species cited on the Approved Lists (33) (i.e., M. faeni, $M$. rectivirgula, $M$. angiospora Zhukova, Tsyganov, and Morozov 1968 [34], and M. internatus Agre, Guzeva, and Dorokhova 1974 [1]) cannot be accommodated in Nocardia as presently defined or in any other genus of the Actinomycetales. However, retention of a name in a sense which excludes the type is possible through Rules 23a and 37a of the International Code of Nomenclature of Bacteria (25). Therefore, we propose that the genus name Micropolyspora be conserved on the basis of the following considerations. Since the name Micropolyspora was introduced by Lechevalier et al. (28), it has gained worldwide acceptance by bacteriologists. Consequently, rejection of the name Micropolyspora would cause considerable confusion, especially in the medical literature, where the binomial $M$. faeni is widely used to describe the organism causing farmer's lung disease and other forms of hypersensitivity pneumonitis. We suggest that conservation of the genus name Micropolyspora can be justified by citing Principle 1 of the International Code of Nomenclature of Bacteria (25). The essential aims in nomenclature are as follows: stability of names; to avoid or reject the use of names which may cause error or confusion; and to avoid the useless creation of names. The stability of nomenclature would be served best by conserving the name Micropolyspora, as opposed to introducing a new genus name to accommodate species currently classified in the genus Micropolyspora. Therefore, we request that the Judicial Commission of the International Committee on Systematic Bacteriology issue an opinion conserving genus name Micropolyspora for the species remaining in the genus Micropolyspora.

Definition of a type species presents further problems. $M$. angiospora and $M$. internatus are not well characterized, and it is possible that further studies could lead to reclassification of these organisms in other actinomycete genera $(21,23,24)$. By contrast, the characteristics of $M$. faeni and $M$. rectivirgula have been fully described $(3,7)$, and these two organisms clearly conform to the genus definition of Micropolyspora $(8,29)$. These two species, which were then named "Thermopolyspora polyspora" and "Thermopolyspora rectivirgula," respectively, were found by Kalakoutskii et al. (16) to have similar modes of spore formation and similar cultural characteristics, but synonymy was not proposed; later detailed taxonomic studies by Arden-Jones et al. (3) and Kurup (21) confirmed that they represent a single taxon. Prauser and Momirova (32) reached the same conclusion on the basis of phage sensitivity.

The epithet rectivirgula was first published in 1964 (18) for a species of "Thermopolyspora" on the basis of three isolates obtained from soils from the Pamirs and Spitzbergen. Colonies were described as colorless, yellowish, or faint yellow with no true pigmentation and had well-developed aerial mycelia that were pale yellow, dark cream, or sand color. The mycelium was nonseptate and did not fragment into bacteroid or coccal elements. Spores were formed by "separation of the tip of the conidiophores, by constriction or by cross walls" into straight chains up to 10 spores long on both aerial and substrate mycelia. The spores were spherical, oval, or oblong and 1.2 to $1.5 \mu \mathrm{m}$ in diameter and had a smooth or tuberculate membrane. Subsequently (10), septa were found, and spores were shown to be variable in shape. Transfer to Micropolyspora was proposed in 1970 by Prauser and Momirova (32). The species $M$. rectivirgula is known only by the three original isolates and perhaps two or three others, all from soil $(3,32)$, and has only rarely been referred to in publications. It has never been implicated in hypersensitivity pneumonitis.

The epithet faeni was published in 1968 (9) for isolates that were obtained from hays associated with farmer's lung disease and were originally referred incorrectly to "Thermopolyspora polyspora" (6). In contrast to $M$. rectivirgula, $M$. faeni was described as having orangish yellow to yellowish brown colonies with white aerial mycelia. Although fragmentation of the vegetative mycelium was not observed, intercalary spores were sometimes present. Spore chains were usually up to five spores long and had a beaded appearance in stained preparations due to thick interspore pads. Spores were globose to oval, sometimes irregular, with a smooth membrane and 0.7 to $1.3 \mu \mathrm{m}$ long. $M$. faeni has been isolated frequently, often in very large numbers, from moldy hays and similar substrates in most countries in Europe, east to Finland, Poland, Czechoslovakia, and Yugoslavia, and from the 
United States, Canada, Iceland, Japan, Australia, Iran, and perhaps Kuwait. As the main causative agent of farmer's lung disease and related forms of hypersensitivity pneumonitis, $M$. faeni has been the subject of more than $\mathbf{3 5 0}$ scientific and medical publications and is well known to medical microbiologists.

Thus, there are considerable discrepancies between the original descriptions of $M$. rectivirgula and $M$. faeni, although subsequent studies have shown that these two organisms are similar and that $M$. rectivirgula produces a white aerial mycelium $(3,16,22,23,32)$. Also, when $M$. faeni was described, the taxonomic position of " $T$. rectivirgula" was in doubt. Krassilnikov and co-workers $(16,17)$ had questioned the separate status of "Thermopolyspora" and its distinction from Micropolyspora, but did not classify their new isolate with the specific epithet rectivirgula in the genus Micropolyspora either when they first described it (18) or when they subsequently studied it in more detail (16). The other species placed in the genus "Thermopolyspora" by Krassilnikov and Agre (18), "Thermopolyspora flexuosa," was found to produce spores on the aerial mycelium only (4) and to resemble closely actinomycetes which were then still included in the genus Nocardia (madurae-pelletieri type) but which later formed the nucleus of the new genus Actinomadura Lechevalier and Lechevalier 1970. "T. flexuosa" was also found to have chemotype III walls, as Actinomadura does, in contrast to the chemotype IV walls of the genus Micropolyspora (4). The chemotype IV wall composition of $M$. rectivirgula was only demonstrated subsequently (26). Although we recognize that $M$. rectivirgula has priority under Rule 23a of the International Code of Nomenclature of Bacteria, 1975 revision (25), we believe that $M$. faeni, as proposed by Arden-Jones et al. (3), should be retained as a nomen conservandum (Rule 56b [25]), both in the interest of nomenclatural stability and in order to avoid confusion.

There are precedents for such a request. Principle 1 of the International Code of Nomenclature of Bacteria and Viruses, 1958 revision (14), states that the essential aims of nomenclature are fixity of names and avoidance or rejection of names which may cause error or ambiguity or throw science into confusion. Farmer et al. (11) and Holmes (13) cite this principle in requesting, respectively, conservation of the specific epithet tarda over anguillimortiferum for the organism known as Edwardsiella tarda Ewing and McWhorter 1965 (Approved Lists, 1980) and conservation of the specific epithet liquefaciens over proteamaculans for Serratia liquefaciens (Grims and Hennerty 1931) Bascomb et al. 1971 (Approved Lists, 1980). Holmes (13) also argued that the epithet liquefaciens was well known to clinical microbiologists, whereas the epithet proteamaculans existed only for the type culture. On the basis of common usage of the epithet typhi and in order to minimize confusion in the literature, the Judicial Commission of the International Committee on Bacteriological Nomenclature again cited Principle 1 of the International Code (14) in support of their decision to conserve the epithet typhi over typhosa for the organism of typhoid (15).

In consideration of these arguments, to maintain stable nomenclature for the organisms causing farmer's lung disease, which are well known to medical microbiologists, and to avoid confusion in the literature, especially in light of the misleading description of " $T$. rectivirgula," we. request that the Judicial Commission of the International Committee on Systematic Bacteriology issue an opinion conserving the specific epithet faeni over rectivirgula for the organism known as Micropolyspora faeni (type strain, ATCC 15347). If both proposals are accepted by the Judicial Commission, Micropolyspora faeni should be cited as the new type species of Micropolyspora.

\section{LITERATURE CITED}

1. Agre, N. S., and L. N. Guzeva. 1975. New actinomycete genus: Excellospora gen. nov. Mikrobiologiya 44:518-523. (In Russian.)

2. Agre, N. S., L. N. Guzeva, and L. A. Dorokhova. 1974. A new species of the genus Micropolyspora-Micropolyspora internatus. Mikrobiologiya 43:679-685. (In Russian.)

3. Arden-Jones, M. P., A. J. McCarthy, and T. Cross. 1979. Taxonomic and serological studies on Micropolyspora faeni and Micropolyspora strains from soil bearing the specific epithet rectivirgula. J. Gen. Microbiol. 115:343354.

4. Becker, B., M. P. Lechevalier, and H. A. Lechevalier. 1965. Chemical composition of cell-wall preparations from strains of various form-genera of aerobic actinomycetes. Appl. Microbiol. 13:236-243.

5. Collins, M. D., T. Pirouz, M. Goodfellow, and D. E. Minnikin. 1977. Distribution of menaquinones in actinomycetes and corynebacteria. J. Gen. Microbiol. 100:221230.

6. Corbaz, R., P. H. Gregory, and M. E. Lacey. 1963. Thermophilic and mesophilic actinomycetes in mouldy hay. $\mathrm{J}$. Gen. Microbiol. 32:449-455.

7. Cross, T. 1974. Genus Micropolyspora Lechevalier, Solotorovsky and McDurmont 1961, 13, p. 861-863. In R. E. Buchanan and N. E. Gibbons (ed.), Bergey's manual of determinative bacteriology, 8th ed. The Williams \& Wilkins Co., Baltimore.

8. Cross, T., and M. Goodfellow. 1973. Taxonomy and classification of the actinomycetes, p. 11-112. In G. Sykes and F. A. Skinner (ed.), Actinomycetales: characteristics and practical importance. Academic Press, Inc., London.

9. Cross, T., A. Maciver, and J. Lacey. 1968. The thermophilic actinomycetes in mouldy hay: Micropolyspora faeni sp. nov. J. Gen. Microbiol. 50:351-359.

10. Dorokhova, L. A., N. S. Agre, L. V. Kalakoutskil, and N. A. Krassilnikov. 1969. Fine structure of sporulating hyphae and spores in a thermophilic actinomycete, Micropolyspora rectivirgula. J. Microsc. (Paris) 8:845-854. 
11. Farmer, J. J., D. J. Brenner, and W. A. Clark. 1976. Proposal to conserve the specific epithet tarda over the specific epithet anguillimortiferum in the name of the organism presently known as Edwardsiella tarda. Int. J. Syst. Bacteriol. 26:293-294.

12. Goodfellow, M., and T. Pirouz. 1982. Numerical classification of sporoactinomycetes containing meso-diaminopimelic acid in the cell wall. J. Gen. Microbiol. 128:503-527.

13. Holmes, B. 1980 . Proposal to conserve the specific epithet liquefaciens over the specific epithet proteamaculans in the name of the organism currently known as Serratia liquefaciens (Grimes and Hennerty 1931) Bascomb et al. 1971: request for an opinion. Int. J. Syst. Bacteriol. 30:220-222.

14. International Committee on Bacteriological Nomenclature (ed.). 1958. International code of nomenclature of bacteria and viruses. Iowa State College Press, Ames.

15. International Committee on Bacteriological Nomenclature Judicial Commission. 1963. Opinion 18. Conservation of typhi in the binary combination Salmonella typhi. Int. Bull. Bacteriol. Nomencl. Taxon. 13:31-33.

16. Kalakoutskii, L. V., N. S. Agre, and N. A. Krassilnikov. 1968. Comparative study on some oligosporic actinomycetes. Hind. Antibiol. Bull. 10:254-268.

17. Krassilnikov, N. A. 1964 . Systematic position of ray fungi among the lower organisms. Hind. Antibiot. Bull. 7:1-17.

18. Krassilnikov, N. A., and N. S. Agre. 1964. On two new species of Thermopolyspora. Hind. Antibiot. Bull. 6:97107.

19. Krassilnikov, N. A., N. S. Agre, and G. I. El-Reghistan. 1968. New thermophilic species of the genus Micropolyspora. Mikrobiologiya 37:1065-1075. (In Russian.)

20. Kroppenstedt, R. M., and R. J. Kutzner. 1978. Biochemical taxonomy of some problem actinomycetes. Zentralbl. Bakteriol. Parasitenkd. Infektionskr. Hyg. Abt. 1 Suppl. 6:125-133.

21. Kurup, V. P. 1981. Taxonomic study of some members of Micropolyspora and Saccharomonospora. Microbiologica (Bologna) 4:249-259.

22. Kurup, V. P., and J. N. Fink. 1979. Antigens of Micropolyspora faeni strains. Int. Arch. Allergy Appl. Immunol. 60:140-147.
23. Kurup, V. P., and J. N. Fink. 1979. Antigenic relationships among thermophilic actinomycetes. Sabouraudia 17:163-169.

24. Lacey, J., M. Goodfellow, and G. Alderson. 1978. The genus Actinomadura, Lechevalier and Lechevalier. Zentralbl. Bakteriol. Parasitenkd. Infektionskr. Hyg. Abt. 1 Suppl. 6:107-117.

25. Lapage, S. P., P. H. A. Sneath, E. F. Lessel, V. B. D. Skerman, H. P. R. Seeliger, and W. A. Clark (ed.) 1975. International code of nomenclature of bacteria. 1975 Revision. American Society for Microbiology, Washington, D.C.

26. Lechevalier, H., and M. P. Lechevalier. 1964. Classification des actinomycètes aérobies basée sur leur morphologie et leur composition chimique. Ann. Inst. Pasteur (Paris) 108:662-673.

27. Lechevalier, H. A., M. P. Lechevalier, and B. Becker. 1966. Comparison of the chemical composition of cellwalls of nocardiae with that of other aerobic actinomycetes. Int. J. Syst. Bacteriol. 16:151-160.

28. Lechevalier, H. A., M. Solotorovsky, and C. I. McDurmont. 1961. A new genus of the Actinomycetales: Micropolyspora gen. nov. J. Gen. Microbiol. 26:11-18.

29. Lechevalier, M. P., C. De Bievre, and H. A. Lechevalier. 1977. Chemotaxonomy of aerobic actinomycetes: phospholipid composition. Biochem. Syst. Ecol. 5:249-260.

30. Lechevalier, M. P., and H. A. Lechevalier. 1970. Chemical composition as a criterion in the classification of aerobic actinomycetes. Int. J. Syst. Bacteriol. 20:435-443.

31. Mordarskaya, G., L. N. Guzeva, and N. S. Agre. 1973. Lipids from the mycelia of thermophilic actinomycetes. Mikrobiologiya 72:165-166. (In Russian.)

32. Prauser, H., and S. Momirova. 1970. Phagensensibilität, Zellwand-Zusammensetzung und Taxonomie einiger thermophiler Actinomyceten. Z. Allg. Mikrobiol. 10:219-222.

33. Skerman, V. B. D., V. McGowan, and P. H. A. Sneath (ed.). 1980. Approved lists of bacterial names. Int. J. Syst. Bacteriol. 30:225-420.

34. Zhukova, R. A., V. A. Tsyganov, and V. M. Morozov. 1968. A new species of Micropolyspora-Micropolyspora angiospora (sp. nov.). Mikrobiologiya 97:724-729. (In Russian.) 